\begin{tabular}{|c|c|c|}
\hline BIODIK & $\begin{array}{c}\text { BIODIK: Jurnal IImiah Pendidikan Biologi } \\
\text { ISSN 2580-0922 (online), ISSN 2460-2612 (print) } \\
\text { Volume 07, Nomor 03, Tahun 2021, Hal. 93-104 } \\
\text { Available online at: } \\
\text { https://online-journal.unja.ac.id/biodik }\end{array}$ & BIODIK \\
\hline
\end{tabular}

Research Article

OPEN ACCESS

\title{
Expert Novice Dialog (END) Di Masa Pandemi Covid-19 Untuk Menilai Kemampuan Komunikasi Sains
}

\author{
(Expert Novice Dialogue (End) During The Covid-19 Pandemic To Assess Science \\ Communication Ability)
}

\section{Evi Paojiah*, Suhendar, Gina Nuranti}

Program Studi Pendidikan Biologi, Fakultas Keguruan dan IImu Pendidikan

Universitas Muhammadiyah Sukabumi

JI. R. Syamsudin, S.H. No.50, Kec. Cikole, Kota Sukabumi, Jawa Barat 43113

${ }^{*}$ Corresponding authors: evipaojiah001@gmail.com

\begin{tabular}{|c|c|}
\hline Informasi Artikel & ABSTRACT \\
\hline $\begin{array}{l}\text { Submit: } 17-06-2021 \\
\text { Diterima: } 29 \text { - } 08-2021 \\
\text { Dipublikasikan: } 27-09-2021\end{array}$ & $\begin{array}{l}\text { This research aims to find out the science communication skills of learners who } \\
\text { are assessed by the Expert-Novice Dialog (END) method assisted by google } \\
\text { suite in the Covid-19 pandemic. This study was conducted at Sukabumi City } \\
\text { State High School in April the second week of } 2021 \text {. This research uses } \\
\text { descriptive methods with quantitative approaches. The sampling technique used } \\
\text { in this study is a purposive sampling technique. The subjects used in this study } \\
\text { were } 60 \text { high school X class learners consisting of } 20 \text { Experts and } 40 \text { Novices. } \\
\text { Data retrieval techniques are done digitally assisted by google suite. The } \\
\text { concept of the material chosen is environmental change. The instruments used } \\
\text { in this study are the rubric of science communication skills, observation rubrics, } \\
\text { novice concept tests, and learners' response questionnaires. The results } \\
\text { showed that the science communication skills of learners in one of Sukabumi } \\
\text { City State High Schools assessed by the Expert-Novice Dialog (END) method } \\
\text { assisted by google suite in the Covid-19 pandemic averaged } 67 \% \text { which falls } \\
\text { into the category of "sufficient". Understanding the novice concept is categorized } \\
\text { as "Good" with an average value of } 80.24 \% \text {. Through the response } \\
\text { questionnaire, it is known that the Expert-Novice Dialog Method (END) assisted } \\
\text { by google suite generally helps learners in practicing science communication } \\
\text { skills and understanding concepts. } \\
\text { Keywords: Assessment, Science communication skills, Expert-Novice Dialog } \\
\text { Method (END), Google Suite }\end{array}$ \\
\hline Penerbit & ABSTRAK \\
\hline $\begin{array}{l}\text { Program Studi Pendidikan Biologi } \\
\text { FKIP Universitas Jambi, } \\
\text { Jambi- Indonesia }\end{array}$ & $\begin{array}{l}\text { Penelitian ini bertujuan untuk mengetahui kemampuan komunikasi sains peserta } \\
\text { didik yang dinilai dengan metode Expert-Novice Dialog (END) berbantuan } \\
\text { google suite di masa pandemi Covid-19. Penelitian ini dilakukan di SMA Negeri } \\
\text { Kota Sukabumi pada bulan April minggu kedua tahun } 2021 \text {. Penelitian ini } \\
\text { menggunakan metode deskriptif dengan pendekatan kuantitatif. Teknik } \\
\text { pengambilan sampel yang digunakan pada penelitian ini adalah teknik purposive } \\
\text { sampling. Subjek yang digunakan pada penelitian ini adalah peserta didik kelas } \\
\text { X SMA yang berjumlah } 60 \text { peserta didik terdiri dari } 20 \text { Expert dan } 40 \text { Novice. } \\
\text { Teknik pengambilan data dilakukan secara digital berbantuan google suite. } \\
\text { Konsep materi yang dipilih adalah Perubahan lingkungan. Instrumen yang } \\
\text { digunakan dalam penelitian ini adalah rubrik kemampuan komunikasi sains, } \\
\text { rubrik observasi, tes konsep novice dan angket respon peserta didik. Hasil } \\
\text { penelitian menunjukan bahwa kemampuan komunikasi sains peserta didik di } \\
\text { salahsatu SMA Negeri Kota Sukabumi yang dinilai dengan metode Expert- }\end{array}$ \\
\hline
\end{tabular}


Novice Dialog (END) berbantuan google suite di masa pandemi Covid-19 ratarata sebesar $67 \%$ yang termasuk dalam kategori "cukup". Pemahaman konsep novice dikategorikan "Baik" dengan nilai rata-rata 80,24\%. Melalui angket respon diketahui bahwa Metode Expert-Novice Dialog (END) berbantuan google suite pada umumnya membantu peserta didik dalam melatih kemampuan komunikasi sains dan memahami konsep.

Kata Kunci : Penilaian, Kemampuan komunikasi sains, Metode Expert-Novice Dialog (END), Google Suite

\section{This BIODIK : Jurnal Ilmiah Pendidikan Biologi
Attribution-ShareAlike 4.0 International License)}

\section{PENDAHULUAN}

Pada konteks pembelajaran, kemampuan dalam berkomunikasi dapat dimaknai sebagai kemampuan yang harus dimiliki dan dikuasai oleh seorang peserta didik karena kemampuan ini bertujuan untuk menggali pengetahuan sebanyak-banyaknya serta untuk menyampaikan informasi kepada masyarakat baik secara lisan maupun tulisan (Marfuah, 2017). Komunikasi merupakan bagian penting dalam pembelajaran saintifik dan dasar untuk mengkonstruksi saintifik pengetahuan, oleh karena itu komunikasi sains merupakan salah satu landasan penting bagi pembelajaran sains (Sriyati, Amelia, \& Soniyana, 2018). Kemampuan untuk dapat mengkomunikasikan pengetahuan ilmiah/hasil percobaan disebut juga sebagai kemampuan berkomunikasi sains (Fadly, 2017).

Kemampuan komunikasi peserta didik haruslah diketahui sebagai data yang objektif (Soniyana, 2016). Oleh karena itu diperlukan suatu penilaian yang benar-benar bisa menjaring data kemampuan komunikasi sains peserta didik. Penilaian (assessment) dapat diartikan sebagai proses untuk mendapatkan informasi dalam bentuk apapun yang dapat digunakan untuk dasar pengambilan keputusan tentang peserta didik (Kartika, Sriyono, \& Nur Ngazizah, April, 2016). Instrumen penilaian yang baik berarti menilai apa yang seharusnya dinilai dengan menggunakan alat yang sesuai untuk mengukur suatu kemampuan yang disebut validitas (Uno \& Koni, 2013). Alat ukur yang valid tidak sekedar mampu mengungkapkan data dengan tepat akan tetapi juga memberikan gambaran yang cermat mengenai data tersebut (Pratama, et al., 2014).

Metode penilaian yang dapat digunakan dan sudah terbukti validitasnya untuk menilai kemampuan komunikasi sains peserta didik adalah Metode Expert-Novice Dialog (END) yang dikembangkan oleh Kulgemeyer \& Schecker (2013). Dengan menggunakan metode penilaian ini, pendidik dapat menilai kemampuan komunikasi sains dari setiap peserta didik dengan baik, bukan hanya dilihat dari kegiatan presentasi yang sebagian besar peserta didik membaca materi baik dari buku, internet atau yang lainnya. Penilaian komunikasi sains peserta didik dengan metode ini tidak mesti dilakukan saat pembelajaran berlangsung, tetapi dapat dilakukan di luar pembelajaran karena komunikasi sains peserta didik terekam dalam bentuk audio (Herliana, 2016). Metode Expert-Novice Dialog (END) merupakan suatu metode penilaian yang berfokus pada penjelasan verbal dengan menggunakan grafik atau gambar sebagai alat bantunya. Metode Expert-Novice Dialog (END) ini memiliki 15 indikator kemampuan komunikasi sains dengan 3 kategori yaitu kategori kognitif, konten pengetahuan dan kategori kemamuan.

Namun, menyebarnya penyakit Covid-19 yang disebabkan oleh Savere Acute Respiratory syndrome corona virus 2 (SARS-CoV2) atau yang lebih dikenal dengan nama virus corona di dunia khususnya di Indonesia saat ini berdampak pada segala aspek kehidupan, salahsatunya pada sektor 
pendidikan. Berubahnya tata kelola kebijakan pendidikan di masa pandemi Covid-19 ini mengakibatkan beralihnya pembelajaran tatap muka di ruang kelas menuju pembelajaran daring (online). Hal ini dilakukan sebagai upaya pencegahan dalam penyebaran penyakit Covid-19 (Wulandari \& Agustika, 2020). Oleh karena itu, diperlukan inovasi tambahan sebagai media di dalam proses pengambilan dan pengumpulan data yang bertujuan untuk membantu terlaksananya penilaian kemampuan komunikasi sains di masa pandemi Covid-19. Adapun inovasi tambahan yang digunakan pada penelitian ini adalah layanan terintegrasi yang disediakan oleh google yang disebut dengan google suite.

Google suite merupakan layanan untuk dunia pendidikan yang dipersembahkan oleh google yang dapat dijadikan sebagai salah satu solusi untuk komunikasi sehingga menjadi solusi berkolaborasi dalam kegiatan pembelajaran (Talib, Suaedi, \& Ilyas, 2021). Google Suite merupakan sistem terintegrasi yang dapat digunakan untuk manajemen institusi berbasis email Gmail yang sekaligus dapat diakses dengan aplikasi mobile (Raharjo, Sebastian, Chrismanto, \& Saputra, 2019). Adapun fitur-fitur yang terdapat pada google suite ini diantaranya yaitu Google Docs, Sheets, Forms, Drive, Meet, Calendar dan sebagainya, termasuk Google Classroom untuk pembelajaran online.

Konsep yang dipilih dalam penelitian ini adalah perubahan lingkungan dengan sub konsep pencemaran lingkungan, limbah dan daur ulang limbah. Konep ini dipilih karena informasinya sangat berkaitan dengan kehidupan sehari-hari, sehingga diharapkan novice (penerima informasi) dapat tertarik dan paham dalam menerima informasi yang disampaikan oleh expert (pemberi informasi).

Berdasarkan latarbelakang yang telah dipaparkan diatas, maka tujuan penelitian ini adalah untuk mengetahui bagaimana kemampuan komunikasi sains peserta didik di salahsatu SMA Negeri Kota Sukabumi yang dinilai dengan metode Expert-novice Dialog (END) berbantuan google suite pada konsep perubahan lingkungan. Penelitian ini diharapkan dapat menjadi gambaran profil kemampuan komunikasi sains dan kategori-kategori yang membangun kemampuan komunikasi sains peserta didik, sehingga dapat mempermudah pendidik menerapkan model atau pendekatan pembelajaran yang dibutuhkan oleh peserta didik dalam upaya meningkatkan kemampuan komunikasi sains peserta didik. Selain itu, metode Expert-Novice Dialog (END) berbantuan google suite diharapkan dapat dijadikan sebagai acuan dalam menilai kemampuan komunikasi sains peserta didik.

\section{METODE PENELITIAN}

Penelitian ini menggunakan metode deskriptif dengan pendekatan kuantitatif. Penelitian ini dilakukan di SMA Negeri Kota Sukabumi pada bulan April minggu kedua tahun 2021. Subjek pada penelitian ini adalah peserta didik yang mendapatkan mata pelajaran biologi kelas X SMA Negeri Kota Sukabumi yang terdiri dari dua kelas berjumlah 60 peserta didik. Subjek penelitian ini dibagi menjadi dua kelompok, pertama peserta didik didik yang berperan sebagai sebagai expert (pemberi informasi) dengan memilih 20 peserta didik dengan nilai rata-rata ujian harian biologi tertinggi di kelas. Kedua, peserta didik yang berperan sebagai novice (penerima informasi) adalah sisa dari total jumlah peserta didik yang berjumlah 40 peserta didik. Teknik pengambilan sampel yang digunakan pada penelitian ini adalah teknik purposive sampling yaitu teknik pengambilan sampel dengan cara mengambil subjek bukan didasarkan atas strata, random atau daerah tetapi didasarkan atas adanya tujuan tertentu atau dengan pertimbangan tertentu (Sugiyono, 2016). Konsep yang dipilih adalah perubahan lingkungan dengan sub konsep pencemaran lingkungan, limbah dan daur ulang limbah.

Instrumen yang digunakan dalam penelitian ini yaitu pertama, rubrik kemampuan komunikasi sains yang di adaptasi dari Kulgemeyer \& Schecker (2013) terdiri dari 3 kategori dengan 15 indikator. Pelaksanaan penelitian direkam secara digital dengan sebuah aplikasi kemudian ditranskrip berdasarkan 
rubrik penilaian tersebut. Hasil penilaian rubrik ini akan dijadikan sebagai data utama pada penelitian ini. Kedua, rubrik observasi yaitu rubrik yang digunakan oleh observer dalam menilai kemampuan komunikasi sains peserta didik langsung melalui video pembelajaran. Rubrik ini terdiri dari 6 indikator berdasarkan pendapat dari Kulgemeyer \& Schecker (2013) yang menyatakan bahwa penjelasan expert (pemberi informasi) dinyatakan baik jika keenam indikator ini muncul. Hasil penilaian rubrik ini akan dijadikan sebagai data pendukung. Ketiga, tes penguasaan konsep untuk peserta didik yang berperan sebagai novice (penerima informasi) bertujuan untuk mengidentifikasi pemahaman konsep materi yang dijelaskan oleh expert (pemberi informasi). Hasil penilaian instrumen ini akan dijadikan sebagai data pendukung. Keempat, angket respon peserta didik yang digunakan untuk mengetahui respon peserta didik terhadap metode Expert-Novice Dialog (END) berbantuan google suite yang digunakan dalam proses pembelajaran.

Analisis rubrik kemampuan komunikasi sains dan rubrik observasi yang dilakukan dengan metode Expert-Novice Dialog (END) menurut Kulgemeyer \& Schecker (2013). Setelah persentase dari analisis rubrik kemampuan komunikasi sains didapatkan, maka kemampuan komunikasi sains tersebut dapat dikategorikan berdasarkan Purwanto (2006) pada pada Tabel.1.

Tabel 1. Kategori Kemampuan Komunikasi

\begin{tabular}{cc}
\hline Presentase & Kategori \\
\hline $86 \%-100 \%$ & Sangat Baik \\
$76 \%-85 \%$ & Baik \\
$60 \%-75 \%$ & Cukup \\
$46 \%-59 \%$ & Kurang \\
$\leq 45 \%$ & Kurang Sekali \\
\hline
\end{tabular}

Pengambilan data pada penelitian ini dilakukan secara digital dengan berbantuan google suite. Aplikasi yang termasuk ke dalam google suite ini terdiri dari google meet yang dijadikan sebagai media pembelajaran utama, google meet breakout rooms dijadikan sebagai media untuk berdiskusi setiap kelompok expert dan novice, google classroom dijadikan sebagai media untuk pengumpulan daftar hadir dan tugas dan google form dijadikan sebagai media untuk pengisian tes dan angket respon peserta didik.

\section{HASIL PENELITIAN DAN PEMBAHASAN}

Kemampuan komunikasi sains peserta didik pada penelitian ini dinilai dengan metode ExpertNovice Dialog (END) berbantuan google suite. Penilaian kemampuan komunikasi sains dilakukan dengan cara menganalisis transkip rekaman video pembelajaran dengan menggunakan rubrik kemampuan komunikasi sains yang terdiri dari 15 indikator tercantum dalam metode Expert-Novice Dialog (END) yang diadaptasi dari Kulgemeyer \& Schecker (2013). Metode Expert-Novice Dialog berfokus pada penjelasan verbal pemberian informasi yang didukung dengan penggunaan grafik atau gambar. Menurut Kulgemeyer \& Schecker (2013) penjelasan oral merupakan inti komunikatif dari penjelasan. Kemudian, penilaian kemampuan komunikasi lainnya didapatkan berdasarkan video pembelajaran langsung yang menggunakan rubrik observasi yang berfokus pada 6 indikator diantaranya yaitu menyiapkan pengantar, menghasilkan atau menggunakan gambar atau grafik, menunjukan pesan secara langsung kepada penerima informasi, mengkonfirmasi pemahaman, memberikan jawaban ringkas dan memberikan contoh. Menurut Kulgemeyer \& Schecker (2013) penjelasan yang termasuk dalam kategori baik jika keenam indikator tersebut muncul. 
Penelitian ini dilakukan dengan melibatkan 20 orang peserta didik yang berperan sebagai expert (pemberi informasi) dan 40 orang peserta didik yang berperan sebagai novice (penerima informasi). Setiap expert (pemberi informasi) menjelaskan informasi yang terdapat di lembar informasi mengenai konsep perubahan lingkungan dengan sub konsep pencemaran lingkungan, limbah dan daur ulang limbah. Konsep ini dipilih karena informasinya sangat berkaitan dengan kehidupan sehari-hari, sehingga diharapkan novice (penerima informasi) dapat tertarik dan paham dalam menerima informasi. Lembar infrmasi dirancang suapaya indikator dalam penilaian kemampuan komunikasi sains itu muncul.

Setelah penelitian dilaksanakan, masing-masing indikator penilaian kemampuan komunikasi sains peserta didik tersebut dikategorikan berdasarkan kategori Purwanto (2006). Berikut adalah tabel dan grafik penilaian kemampuan komunikasi sains peserta didik berdasarkan hasil penelitian :

Tabel. 2 Kategorisasi Hasil Penilaian Kemampuan Komunikasi Sains Expert untuk Setiap Indikator Berdasarkan Analisis Transkip Video

\begin{tabular}{|c|c|c|c|c|}
\hline No. & Indikator & $\begin{array}{c}\text { Jumlah Expert } \\
\text { Memunculkan Indikator }\end{array}$ & $\begin{array}{l}\text { Persentase } \\
\quad(\%)\end{array}$ & $\begin{array}{l}\text { Kategori } \\
\text { Penilaian }\end{array}$ \\
\hline \multicolumn{5}{|c|}{ Kategori Kognitif (Cognitive Categories) } \\
\hline 1 & Memberikan contoh & 20 & $100 \%$ & Sangat Baik \\
\hline 2 & $\begin{array}{l}\text { Menghasilkan atau menggunakan } \\
\text { gambar/grafik }\end{array}$ & 16 & $80 \%$ & Baik \\
\hline 3 & Menghubungkan gambar/grafik & 5 & $25 \%$ & Kurang Sekali \\
\hline 4 & $\begin{array}{l}\text { Memvariasikan model pada saat } \\
\text { menjelaskan }\end{array}$ & 15 & $75 \%$ & Cukup \\
\hline 5 & Memvariasikan level abstraksi & 10 & $50 \%$ & Kurang \\
\hline 6 & $\begin{array}{l}\text { Memvariasikan bentuk kalimat } \\
\text { saintifik }\end{array}$ & 14 & $70 \%$ & Cukup \\
\hline \multicolumn{5}{|c|}{ Pengetahuan konten (Content Knowledge) } \\
\hline 7 & $\begin{array}{l}\text { Memberikan jawaban ringkas, } \\
\text { jelas dan tepat }\end{array}$ & 16 & $80 \%$ & Baik \\
\hline \multicolumn{5}{|c|}{ Kategori Kemauan (Volitional Categories) } \\
\hline 8 & $\begin{array}{l}\text { Tidak ada interupsi jika penerima } \\
\text { informasi berbicara }\end{array}$ & 16 & $80 \%$ & Baik \\
\hline 9 & Mengkonfirmasikan pemahaman & 10 & $50 \%$ & Kurang \\
\hline 10 & $\begin{array}{l}\text { Menunjukan pesan secara } \\
\text { langsung }\end{array}$ & 15 & $75 \%$ & Cukup \\
\hline 11 & Menanyakan pengetahuan awal & 11 & $55 \%$ & Kurang \\
\hline 12 & Menanyakan kebutuhan & 20 & $100 \%$ & Sangat Baik \\
\hline 13 & Menyiapkan pendahuluan & 8 & $40 \%$ & Kurang Sekali \\
\hline 14 & $\begin{array}{l}\text { Menyelidiki pengetahuan dasar di } \\
\text { awal penjelasan }\end{array}$ & 7 & $35 \%$ & Kurang Sekali \\
\hline \multirow[t]{2}{*}{15} & Memperkenalkan topik & 18 & $90 \%$ & Sangat Baik \\
\hline & Rata-rata & & $67 \%$ & Cukup \\
\hline
\end{tabular}

Berdasarkan tabel 2. diatas dapat diketahui bahwa kemampuan komunikasi sains peserta didik di salahsatu SMA Negeri Kota Sukabumi di masa pandemi Covid-19 termasuk ke dalam kategori cukup dengan nilai rata-rata $67 \%$. Hasil penilaian kemampuan komunikasi sains peserta didik yang berperan sebagai expert (pemberi informasi) untuk setiap kategori yaitu; 


\section{Cognitive Categories (Kategori Kognitif)}

a. Memberikan contoh, yaitu menggunakan contoh yang tepat dan menghubungkan contoh tersebut dalam kejadian sehari-hari. Indikator ini digunakan untuk membantu penerima informasi supaya lebih mudah memahami informasi yang dijelaskan oleh pemberi informasi. Hasil penelitian menunjukan bahwa indikator memberikan contoh termasuk ke dalam kategori "Sangat Baik" dengan persentase $100 \%$. Hal ini dikarenakan seluruh expert (pemberi informasi) yang berjumlah 20 orang memberikan contoh ketika menjelaskan konsep kepada novice (penerima informasi). Contoh yang digunakan expert (pemberi informasi) tersebut berasal dari lembar informasi yang telah diberikan oleh peneliti sebelumnya. Indikator memberikan contoh ini dapat membantu meningkatkan pemahaman konsep peserta didik. Hal ini sesuai dengan pendapat Suherman (2010) yang menyebutkan bahwa pemahaman peserta didik terhadap konsep baru dapat ditingkatkan melalui pemberian contoh yang jelas dan nyata yang sedapat mungkin diambil dari kehidupan sehari-hari yang sekiranya mudah dicerna atau dipahami oleh peserta didik tersebut tersebut.

b. Menghasilkan atau menggunakan gambar/grafik, hasil penelitian menunjukan bahwa indikator menghasilkan atau menggunakan gambar/grafik termasuk dalam katgeori "Baik" dengan persentase $80 \%$. Gambar atau grafik yang digunakan merupakan suatu media yang bertujuan untuk mempermudah pemberi informasi dalam memvisualisasikan informasi kepada penerima informasi. Menurut Miftah (2013) Media adalah suatu alat atau sarana atau perangkat yang berfungsi sebagai perantara atau saluran atau jembatan dalam kegiatan komunikasi (penyampaian dan penerimaan pesan) antara komunikator (penyapai pesan) dan komunikan (penerima pesan). Penelitian sebelumnya yang telah dilakukan oleh Sriyati, dkk. (2015) menunjukan bahwa indikator menghasilkan atau menggunakan gambar/grafik di kelas A termasuk dalam kategori sangat baik dengan persentase 100\%. Menurut Kulgemeyer \& Schecker (2013) indikator menghasilkan atau menggunakan gambar/grafik merupakan salah satu indikator kemampuan komunikasi sains yang menunjukkan kriteria penjelasan yang baik.

c. Mengaitkan gambar/grafik yaitu menghubungkan beberapa bentuk gambar atau grafik representatif yang berbeda satu sama lain untuk memvisualisasikan informasi yang berhubungan agar lebih mudah dipahami (Kulgemeyer, 2013). Hasil penelitian menunjukan bahwa indikator mengaitkan gambar/grafik termasuk dalam kategori "Kurang Sekali" dengan persentase $25 \%$. Hal ini dikarenakan hanya 5 dari 20 orang pemberi informasi yang menghubungkan gambar dan grafik pada saat menjelaskan informasi kepada penerima informasi. Berdasarkan hasil wawancara terhadap peserta didik yang berperan sebagai pemberi informasi, diketahui bahwa pemberi informasi sudah merasa cukup dengan menjelaskan konsep materi hanya dengan menggunakan gambar atau grafik saja tanpa menghubungkannya.

d. Memvariasikan model, yaitu menggunakan dan memvariasikan model-model saintifik dalam proses menjelaskan informasi kepada penerima informasi. Hasil penelitian menunjukan bahwa indikator memvariasikan model termasuk dalam kategori "Cukup" dengan persentase 75\%. Model atau alat peraga ini digunakan apabila benda asli sulit untuk ditampilkan. Alat peraga merupakan media pembelajaran yang mengandung atau membawakan ciri-ciri dari konsep yang dipelajari (Sudjana, 2008).

e. Memvariasikan level abstraksi, yaitu mempermudah penjelasan suatu informasi yang sulit dijelaskan karena informasi tersebut berbentuk abstrak dan sulit diamati dengan menggunakan kalimat yang lebih sederhana pada saat menjelaskan. Hasil penelitian menunjukan bahwa indikator memvariasikan level abstraksi termasuk dalam kategori "Kurang" dengan persentase 50\%. Hal ini 
dikarenakan pemberi informasi sudah merasa cukup menjelaskan informasi yang terdapat di dalam lembar informasi tanpa mengubahnya menjadi kalimat yang lebih sederhana lagi. Menurut Amelia (2005) pada hasil penelitiannya menyebutkan bahwa indikator memvariasikan level abstraksi dapat lebih dimunculkan apabila informasi-informasi yang tergolong abstrak diperjelas, salah satu contohnya adalah dengan memberikan analogi.

f. Memvariasikan bentuk kalimat saintifik, yaitu menyederhanakan sebuah kalimat yang berisikan informasi saintifik menjadi kalimat yang lebih sederhana. Hasil penelitian menunjukan bahwa indikator memvariasikan bentuk kalimat saintifik termasuk dalam kategori "Cukup" dengan persentase $70 \%$. Hal ini dikarenakan pemberi informasi sudah merasa cukup . menjelaskan informasi yang terdapat di dalam lembar informasi.

2. Content Knowledge (Pengetahuan Materi), hanya terdapat satu indikator pada kategori ini; memberikan jawaban yang ringkas, yaitu pemberi informasi memberikan jawaban langsung pada pertanyaan tentang istilah saintifik apabila penerima informasi bertanya. Indikator ini hanya muncul jika penerima informasi bertanya dan pemberi informasi menjawab pertanyaan dengan ringkas. Hasil penelitian menunjukan bahwa indikator memberikan jawaban ringkas termasuk dalam kategori "Baik" dengan persentase $80 \%$. Hal ini berarti sekitar 16 dari 20 orang pemberi informasi memperhatikan dan mendegarkan pendapat atau pertanyaan lawan bicaranya pada saat proses pembelajaran berlangsung.

\section{Volitional Categories (Kategori Kemauan)}

a. Tidak ada interupsi, yaitu pemberi informasi tidak memberikan interupsi pada saat penerima informasi berbicara. Misalnya ketika penerima informasi memberikan pendapat atau bertanya terkait informasi yang kurang dimengerti. Hasil penelitian menunjukan bahwa indikator tidak ada interupsi termasuk dalam kategori "Baik" dengan persentase $80 \%$. Indikator tidak ada interupsi ini dapat menunjukan sikap expert (pemberi informasi) dalam menghargai pendapat temannya yang berperan sebagai novice (penerima informasi) pada saat berkomunikasi. Menurut Amelia (2005) menghargai pendapat orang lain pada saat berkomunikasi lisan merupakan suatu hal yang penting, karena dalam berkomunikasi lawan bicara merasa dihargai dan akan terjalin suatu komunikasi yang baik.

b. Mengkonfirmasikan pemahaman, yaitu pemberi informasi mengkonfirmasi dan menanyakan kepada penerima informasi mengenai penjelasan atau informasi yang belum dipahami. Misalnya "Mengerti?". Hasil penelitian menunjukan bahwa indikator mengkonfirmasikan pemahaman termasuk dalam kategori "Kurang" dengan persentase 50\%. Hal ini dikarenakan hanya 10 dari 20 orang pemberi informasi yang menanyakan terkait hal tersebut kepada penerima informasi.

c. Menunjukan pesan secara langsung kepada penerima informasi, yaitu pemberi informasi memberi penjelasan 57 ilmiah secara langsung kepada penerima informasi dengan menggunakan kata ganti kedua misalnya, 'kamu' 'kalian'. Hal ini dilakukan agar suasana pada saat dialog dilaksanakan berjalan dalam suasana yang nyaman (Amelia D. , 2005). Hasil penelitian menunjukan bahwa indikator menunjukan pesan secara langsung kepada penerima informasi termasuk dalam kategori "Cukup" dengan persentase 75\%.

d. Menanyakan konsep dasar, yaitu pemberi informasi menanyakan penerima informasi mengenai konsep dasar yang telah diketahui mengenai informasi yang akan dijelaskan. Menurut Astuti ( 2017) Konsep merupakan salah satu pengetahuan awal yang harus dimiliki peserta didik karena konsep merupakan dasar dalam merumuskan prinsip-prinsip. Hasil penelitian menunjukan bahwa indikator menanyakan konsep dasar termasuk dalam kategori "Kurang" dengan persentase 55\%. Penelitian 
ini sesuai dengan hasil penelitian sebelumnya yang telah dilakukan oleh Amelia (2005) menunjukan bahwa indikator menanyakan konsep dasar termasuk dalam kategori "Kurang" dengan persentase $37,5 \%$. Hal ini disebabkan karena indikator menanyakan konsep dasar itu dapat dimunculkan dengan membutuhkan kemauan atau motivasi dari dalam diri pemberi informasi itu sendiri.

e. Menanyakan kebutuhan, yaitu pemberi informasi mencari tahu tentang apa yang diinginkan penerima informasi untuk diketahui lebih lanjut. Hasil penelitian menunjukan bahwa indikator menanyakan kebutuhan termasuk dalam kategori "Sangat Baik" dengan persentase 100\%. Hal ini dikarenakan seluruh peserta didik yang berperan sebagai pemberi informasi menanyakan apa yang ingin diketahui lebih lanjut oleh penerima informasi.

f. Menyiapkan pendahuluan, indikator ini bertujuan agar novice (penerima informasi) tertarik dengan informasi yang akan dijelaskan oleh pemberi informasi. Indikator ini dapat dimunculkan dengan menunjukan relevansi antara topik yang akan dijelaskan dengan kejadian sehari-hari sebagai pembuka atau pengantar dari suatu informasi yang akan disampaikan. Hasil penelitian menunjukan bahwa indikator menyiapkan pendahuluan termasuk dalam kategori "Kurang Sekali" dengan persentase $40 \%$. Berdasarkan hasil wawancara tambahan terhadap peserta didik yang berperan sebagai pemberi informasi, diketahui sebagian besar pemberi informasi merasa bahwa dengan menjelaskan pengertian dari topik yang akan dibahas tanpa menunjukan relevansinya dengan kehidupan sehari-hari itu sudah termasuk dalam indikator menyiapkan pendahuluan. Pada penelitian sebelumnya yang telah dilakukan oleh Amelia (2005) indikator menyiapkan pendahuluan termasuk dalam kategori sangat baik dengan persentase $100 \%$. Hal ini dikarenakan expert (pemberi informasi) pada penelitian tersebut memiliki kemampuan perencanaan yang baik sehingga mampu menyiapkan pendahuluan yang memiliki relevansi dengan kejadian sehari-hari dengan baik. Dengan diberikannya pengantar yang memiliki relevansi dengan kejadian sehari-hari, proses penjelasan informasi yang dilakukan oleh pemberi informasi menjadi lebih menarik karena mempermudah penerima informasi dalam mencerna informasi (Amelia D. , 2005).

g. Menyelidiki pengetahuan dasar di awal penjelasan, yaitu pemberi informasi menanyakan pengetahuan awal penerima informasi mengenai konsep yang akan dibahas di awal penjelasan. Hasil penelitian menunjukan bahwa indikator menyelidiki pengetahuan dasar di awal penjelasan termasuk dalam kategori "Kurang Sekali" dengan persentase 35\%. Hal ini dikarenakan hanya 7 dari 20 orang pemberi informasi yang menanyakan pengetahuan awal penerima informasi. Hasanuddin (2020) menyebutkan pada prinsipnya pengetahuan awal peserta didik dapat membantu (help) maupun dapat menghambat (hinder) pembelajaran. Sehingga harus ada upaya yang dilakukan untuk mengidentifikasi dan mengetahui sejauh mana pengetahuan awal peserta didik relevan dalam pembelajaran. Upaya tersebut terdapat di dalam indikator ini. Akan tetapi, indikator menyelidiki pengetahuan dasar di awal penjelasan merupakan membutuhkan kemauan dari dalam diri pemberi informasi sendiri. Oleh karena itu, kemunculan dari indikator ini adalah tergantung kepada motivasi pemberi informasi itu sendiri.

h. Memperkenalkan topik, yaitu pemberi informasi memberitahukan mengenai nama topik di awal. Hasil penelitian menunjukan bahwa indikator memperkenalkan topik termasuk dalam kategori "Sangat Baik" dengan persentase 90\%. Hal ini dikarenakan 18 dari 20 orang pemberi informasi memberitahukan topik yang akan dijelaskan oleh pemberi informasi tersebut yaitu "Perubahan lingkungan" pada awal penjelasan. 
Selanjutnya terdapat hasil dari penilaian rubrik observasi yang dilakukan langsung pada video pembelajaran yang direkam pada grafik berikut ini :

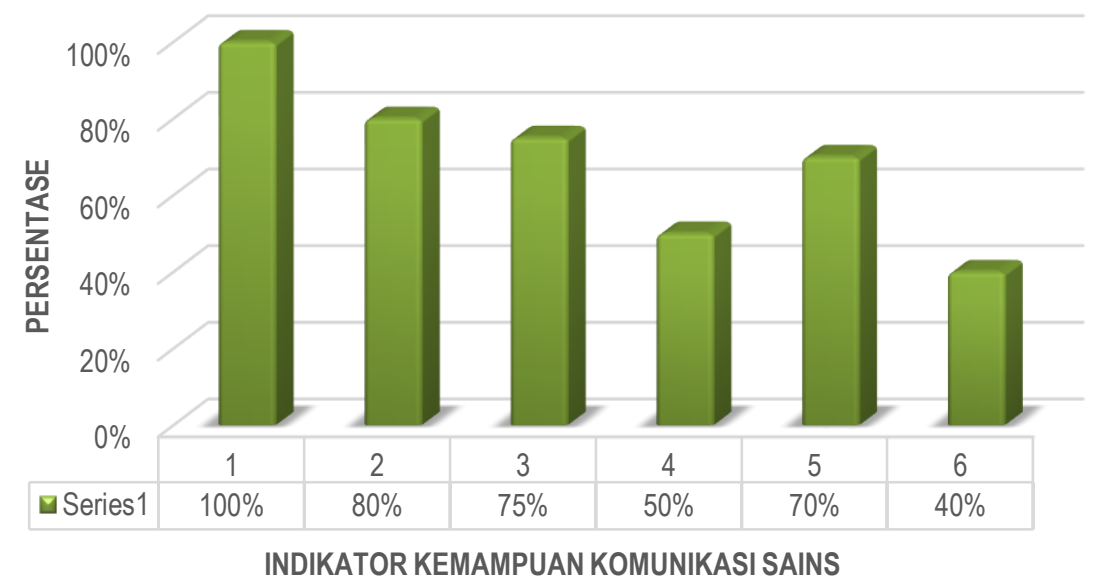

Gambar 1. Kemampuan komunikasi sains berdasarkan analisis observer

\section{Keterangan :}

1. Memberikan contoh

2. Menghasilkan atau menggunakann gambar atau grafik

3. Memberikan jawaban ringkas

4. Mengkonfirmasi pemahaman

5. Menunjukan pesan secara langsung

6. Menyiapkan pendahuluan

Berdasarkan data pada Gambar 1. diatas dapat diketahui bahwa hasil penilaian pada rubrik observer mendukung dan sesuai dengan data utama yang telah disajikan sebelumnya. Dimana, indikator memberikan contoh termasuk ke dalam kategori sangat baik dengan persentase 100\%. Kemudian, indikator menghasilkan atau menggunakan gambar atau grafik termasuk dalam kategori baik dengan persentase $80 \%$. Indikator memberikan jawaban ringkas dan menunjukan pesan secara langsung termasuk ke dalam kategori cukup. Selanjutnya indikator mengkonfirmasi pemahaman dan menyiapkan pendahuluan memiliki presentase yang kecil yaitu secara berurutan termasuk dalam kategori kurang dan kurang sekali dengan persentase $50 \%$ dan $40 \%$.

Setelah novice (penerima informasi) mendapatkan penjelasan dari expert (pemberi informasi), novice (penerima informasi) diberikan soal tes yang disesuaikan dengan informasi yang diberikan oleh expert (pemberi informasi). Adapun tujuan dari pemberian tes ini yaitu untuk mengetahui pemahaman konsep peserta didik yang berperan sebagai novice (penerima informasi) setelah dilakukannya metode Expert-Novice Dialog (END) berbantuan google suite di masa pandemi Covid-19. Hasil dari tes pemahaman konsep ini akan dijadikan sebagai data pendukung. Berikut ini tabel hasil tes pemahaman konsep novice (penerima informasi) berdasarkan hasil penelitian : 
Tabel. 3 Hasil Pemahaman Konsep Novice (penerima informasi)

\begin{tabular}{|c|c|c|c|c|}
\hline No. & $\begin{array}{l}\text { Kelompok } \\
\text { Expert }\end{array}$ & Novice & $\begin{array}{l}\text { Nilai novice } \\
\text { perindividu }\end{array}$ & $\begin{array}{c}\text { Rata-rata nilai novice } \\
\text { perkelompok }\end{array}$ \\
\hline \multirow{2}{*}{1.} & \multirow[b]{2}{*}{ Expert 1} & Novice 1 & 80,95 & \multirow{2}{*}{80,95} \\
\hline & & Novice 2 & 80,95 & \\
\hline \multirow{2}{*}{2.} & \multirow{2}{*}{ Expert 2} & Novice 1 & 80,95 & \multirow{2}{*}{76,19} \\
\hline & & Novice 2 & 71,43 & \\
\hline \multirow{2}{*}{3.} & \multirow{2}{*}{ Expert 3} & Novice 1 & 76,19 & \multirow{2}{*}{71,43} \\
\hline & & Novice 2 & 66,67 & \\
\hline \multirow{2}{*}{4.} & \multirow{2}{*}{ Expert 4} & Novice 1 & 71,43 & \multirow{2}{*}{78,57} \\
\hline & & Novice 2 & 85,71 & \\
\hline \multirow{2}{*}{5.} & \multirow{2}{*}{ Expert 5} & Novice 1 & 80,95 & \multirow{2}{*}{83,33} \\
\hline & & Novice 2 & 85,71 & \\
\hline \multirow{2}{*}{6.} & \multirow{2}{*}{ Expert 6} & Novice 1 & 76,19 & \multirow{2}{*}{73,81} \\
\hline & & Novice 2 & 71,43 & \\
\hline \multirow{2}{*}{7.} & \multirow{2}{*}{ Expert 7} & Novice 1 & 85,71 & \multirow{2}{*}{78,57} \\
\hline & & Novice 2 & 71,43 & \\
\hline \multirow{2}{*}{8.} & \multirow{2}{*}{ Expert 8} & Novice 1 & 85,71 & \multirow{2}{*}{83,33} \\
\hline & & Novice 2 & 80,95 & \\
\hline \multirow{2}{*}{9.} & \multirow{2}{*}{ Expert 9} & Novice 1 & 85,71 & \\
\hline & & Novice 2 & 90,48 & 88,10 \\
\hline 10 & Eynort 10 & Novice 1 & 90,48 & \\
\hline 10. & Expert 10 & Novice 2 & 71,43 & 80,95 \\
\hline 11 & Fxnert 11 & Novice 1 & 85,71 & 8333 \\
\hline 11. & Expert II & Novice 2 & 80,95 & 83,33 \\
\hline 12 & Fxnert 12 & Novice 1 & 85,71 & 8095 \\
\hline 12. & Expert IL & Novice 2 & 76,19 & 80,90 \\
\hline 13 & & Novice 1 & 76,19 & 6905 \\
\hline 13. & Expert 13 & Novice 2 & 61,90 & 69,05 \\
\hline 14 & Fxnert 14 & Novice 1 & 85,71 & 8810 \\
\hline 14. & Expert 14 & Novice 2 & 90,48 & 88,10 \\
\hline & & Novice 1 & 85,71 & 8333 \\
\hline 15. & Expert 15 & Novice 2 & 80,95 & 83,33 \\
\hline 16 & Fxnert 16 & Novice 1 & 90,48 & 8571 \\
\hline 10. & Expert 10 & Novice 2 & 80,95 & 85,11 \\
\hline 17 & Fynert 17 & Novice 1 & 95,24 & 8333 \\
\hline 11. & Expert 11 & Novice 2 & 71,43 & 83,33 \\
\hline 18 & Fxnert 18 & Novice 1 & 80,95 & 8095 \\
\hline 10. & Expert 18 & Novice 2 & 80,95 & 80,90 \\
\hline 19 & Eynert 10 & Novice 1 & 71,43 & \\
\hline 19. & Expert 79 & Novice 2 & 76,19 & 73,81 \\
\hline 20 & Eynert 20 & Novice 1 & 85,71 & \\
\hline 20. & Expert 20 & Novice 2 & 76,19 & 80,95 \\
\hline & & Rata-rata & & 80,24 \\
\hline
\end{tabular}

Berdasarkan Tabel. 3 diatas dapat diketahui bahwa pemahaman konsep peserta didik yang berperan sebagai novice (penerima informasi) memiliki nilai di atas KKM, yaitu 75. Data tersebut diketahui karena pada tabel diatas terdapat 31 dari 40 peserta didik yang berperan sebagai novice (penerima informasi) nilainya diatas 75 atau sekitar $80,24 \%$ penerima informasi memiliki nilai di atas KKM. Hal ini berarti rata-rata pemahaman informasi peserta didik yang berperan sebagai penerima informasi termasuk ke dalam kategori "baik" (Purwanto, 2006). Berdasarkan hasil pemahaman konsep novice (penerima informasi) dapat diketahui bahwa pada penelitian ini kemampuan komunikasi expert (pemberi informasi) dalam menyampaikan konsep kepada novice (penerima informasi) itu sudah berhasil. Hal ini sesuai 
dengan pernyataan menurut Kulgemeyer \& Schecker (2013) Kemampuan komunikasi sains peserta didik berdasarkan Expert-Novice Dialog (END) berhasil apabila expert (pemberi informasi) berhasil melakukan penjelasan dengan baik kepada novice (penerima informasi).

Hasil analisa angket respon peserta didik pada penelitian menunjukan bahwa sebagian besar peserta didik tertarik belajar menggunakan metode Expert-Novice Dialog (END) berbantuan google suite. Hal ini dikarenakan metode Expert-Novice Dialog (END) berbantuan google suite selain dapat mengukur kemampuan komunikasi sains juga membantu dalam melatih kemampuan komunikasi sains peserta didik. Dari pernyataan pada angket respon tersebut juga diketahui sebagian besar peserta didik belum memiliki kemampuan komunikasi sains sebelum berlangsungnya pembelajaran, akan tetapi setelah melakukan pembelajaran dengan menggunakan metode Expert-Novice Dialog (END) berbantuan google suite sebagian besar peserta didik merasa kemampuan komunikasi sainsnya meningkat.

Selain itu, sebagian besar peserta didik juga menyebutkan bahwa metode Expert-Novice Dialog (END) berbantuan google suite membantu untuk melatih kemampuan komunikasi sains dan membantu dalam memahami konsep materi Perubahan lingkungan. Berdasarkan hasil analisa angket respon peserta didik tersebut diketahui bahwa pembelajaran dengan menggunakan metode Expert-Novice Dialog (END) berbantuan google suite mendapat respon positif dari peserta didik.

\section{SIMPULAN}

Berdasarkan hasil penelitian dapat disimpulkan bahwa kemampuan komunikasi sains peserta didik yang dinilai dengan Metode Expert-Novice Dialog (END) berbantuan google suite di masa pandemi Covid-19 pada salahsatu SMA Negeri Kota Sukabumi menunjukkan nilai rata-rata 67\% yang termasuk ke dalam kategori "cukup". Pemahaman konsep peserta didik yang berperan sebagai novice (penerima informasi) termasuk dalam kategori "baik" dengan nilai persentase rata-rata sebesar 80,24\%. Berdasarkan hasil angket respon peserta didik diketahui bahwa Metode Expert-Novice Dialog (END) berbantuan google suite mendapat respon positif dari peserta didik. Pada umumnya metode ExpertNovice Dialog (END) berbantuan google suite membantu peserta didik dalam melatih kemampuan komunikasi sains dan memahami konsep.

\section{UCAPAN TERIMA KASIH}

Penelitian ini dapat dilaksanakan dengan baik berkat bantuan dari berbagai pihak, untuk itu peneliti mengucapkan terimakasih kepada salahsatu SMA Negeri Kota Sukabumi yang telah membantu dalam melaksanakan penelitian yang berjudul "Expert-Novie Dialog (END) di Masa Pandemi Covid-19 untuk Menilai Kemampuan Komunikasi Sains".

\section{RUJUKAN}

Amelia, D. (2005). Kemampuan Komunikasi Sains Peserta didik Sma Pada Konsep Ekosistem Yang Dinilai Dengan Metode Expert-Novice Dialog. Bandung: Universitas Pendidikan Indonesia.

Astuti, L. S. ( 2017). Penguasaan Konsep IPA Ditinjau Dari Konsep Diri Dan Minat Belajar Peserta didik . Jurnal Formatif , 7(1) : Hal. 42.

Fadly, W. (2017). Efektivitas Pembelajaran Fisika "Produksi" Terhadap Peningkatan Aspek-Aspek Keterampilan Berkomunikasi Sains. Jurnal Kependidikan Dasarislam Berbasis Sains, Volume 2, Nomor 1, Hal. 84. 
Hasanuddin, M. I. (2020). Pengetahuan Awal (Prior Knowledge) : Konsep Dan Implikasi Dalam Pembelajaran. Edisi : Jurnal Edukasi Dan Sains, Volume 2, Nomor 2, Agustus.

Herliana, L. (2016). Penggunaan Metode Expert-Novice Dialog Untuk Menilai Kemampuan Komunikasi Sains Peserta didik Pada Materi Perpindahan Kalor Secara Konduksi. Bandung: Universitas Muhammadiyah Sukabumi.

Kartika, D., Sriyono, \& Nur Ngazizah. (April, 2016). Pengembangan Instrumen Untuk Mengukur Kemampuan Komunikasi Sains Peserta didik Sma. Jurnal Radiasi Volume 08 No.1, Volume 08 No.1, Hal. 29.

Kulgemeyer, C. \&. (2013). Students Explaining Science Assessment Of Science Communication Competence. Res Sci Educ.

Marfuah. (2017). Meningkatkan Keterampilan Komunikasi Peserta Didik Melalui Model Pembelajaran Kooperatif Tipe Jigsaw. Jurnal Pendidikan IImu Sosial, Volume 26, Nomor 2.

Miftah, M. (2013). Fungsi Dan Peran Media Pembelajaran Sebagai Upaya Peningkatan Kemampuan Belajar Peserta didik. Jurnal Kwangsan, Vol. 1, Nomor 2 Hal.97 Desember.

Pratama, A. Y., Irawan, A., Uswandari, B. D., Cahyati, I., Minarsih, Laila, R. N., . . Ruzni, A. (2014). Ulasan Deskriptif Validitas Dalam Suatu Alat Ukur. Seminar Nasional Psikologi Ums, Hal. 103.

Purwanto. (2006). Prinsip-Prinsip Dan Teknik Evaluasi Pengajaran. . Bandung: Rosdakarya.

Raharjo, W. S., Sebastian, D., Chrismanto, A. R., \& Saputra, L. K. (2019). Pemanfaatan G Suite For Education Untuk Meningkatkan Efektifitas Belajar Mengajar Dan Kapasitas Guru Sma. Prosiding Seminar Nasional Hasil Pengabdian Kepada Masyarakat, HIm. 100 Vol. 4 No. 1.

Soniyana, G. T. (2016). Kemampuan Komunikasi Sains Peserta didik Pada Konsep Klasifikasi Tumbuhan Menggunakan Analisis Fenetik Yang Dinilai Dengan Metode Expert-Novice Dialog. Bandung: Universitas Pendidikan Indonesia.

Sriyati, S., Amelia, D., \& Soniyana, G. (2018). Application Of Expert-Notice Dialogue (End) Method To Assess. Journal Of Physics, HIm.1.

Sudjana, N. (2008). Penilaian Hasil Proses Belajar Mengajar. Bandung: Pt Remaja Rosdakarya.

Sugiyono. (2016). Metode Penelitian Kuantitatif Kualitatif Dan R\&D. Bandung: Alfabeta.

Talib, A., Suaedi, \& llyas, M. (2021). Pembelajaran Matematika Berbasis Google Suite For Education Untuk Meningkatkan Kecakapan Kolaboratif Peserta didik. Teorema: Teori Dan Riset Matematika, Hal.36.

Uno, H., \& Koni, S. (2013). Assesment Pembelajaran. Jakarta: Bumi Aksara.

Wulandari, I. A., \& Agustika, G. (2020). Dramatik Pembelajaran Daring Pada Masa Pandemi Covid-19 (Studi Pada Persepsi Mahapeserta didik Pgsd Undiksha). Jurnal Mimbar Pgsd Undiksha, Vol. 8 No. 3 Hal. 516. 